\title{
Neoplastic Plasma Cells Under 50 Percent of Bone Marrow Nucleated Cells
}

National Cancer Institute

\section{Source}

National Cancer Institute. Neoplastic Plasma Cells Under 50 Percent of Bone Marrow

Nucleated Cells. NCI Thesaurus. Code C153386.

A semi-quantitative microscopic finding indicating that less than 50 percent of the nucleated cells in a bone marrow sample are neoplastic plasma cells. 